\title{
Suggesting a Framework for Performance Evaluation of Tourist Attractions: A Balance Score Approach
}

\author{
Yuejiao Wang ${ }^{1}$, Shiwei Shen ${ }^{1}$, Marios Sotiriadis ${ }^{1, *}$ and Li Zhang ${ }^{2}$ \\ 1 Joint Institute of Ningbo University and Angers University, Ningbo University, 1188 Beihuan East Road, \\ Zhenhai District, Ningbo 315211, China; wangyuejiao@nbu.edu.cn (Y.W.); shenshiwei@nbu.edu.cn (S.S.) \\ 2 School of International Studies, Zhejiang Business Technology Institute, Ningbo 315211, China; \\ 10823039@zjbti.net.cn \\ * Correspondence: sotiriadis@nbu.edu.cn; Tel.: +86-134-8421-4362
}

Received: 24 June 2020; Accepted: 31 July 2020; Published: 2 August 2020

check for updates

\begin{abstract}
The aim of this study is to suggest a framework for performance evaluation of smart tourism initiatives/projects implemented in tourist attractions. The suggested tool is based on the theoretical foundations of Service-Dominant Logic and the Balance Scorecard framework, an established strategic management framework that maps an organization's strategic objectives into performance indicators. The suggested template for performance evaluation was tested and validated within the context of China, and 30 interviews were conducted with managers of tourist attractions rated the highest quality level in Zhejiang Province, China. The empirical study's results indicated that (i) the crafted Balance Scorecard template is implementable and of high utility; (ii) a volume of 8 Critical Success Factors and 22 Key Performance Indicators constitute an integrated set to monitor and assess the performance in a comprehensive manner; (iii) the key factors and indicators should be the same regardless of the type of ownership and management (public or private); and (iv) technological infrastructure and services are evolving; however, the principles and tools remain the same regardless the advent of smart paradigm.
\end{abstract}

Keywords: tourist attractions; smart tourism initiatives; value proposition; performance evaluation; balanced scorecard template

\section{Introduction: Smart Tourism Projects, Value Propositions, and Performance Evaluation}

The application of information and communication technologies (ICTs) for developing innovative tools and approaches to improve tourism has been coined smart tourism (ST) [1]. The ST framework is the result of the widespread of ICTs and the need for sustainability [2,3]. The main aims of ST are to enhance tourism experiences, to improve the efficiency of resource management, and to maximize destination competitiveness with an emphasis on sustainable aspects [2,4-6]. From the technological perspective, ST refers to the competitive advantage resulting from "using a range of smart technologies, such as sensors, beacons, mobile phone apps, radio-frequency identification (RFID), near-field communication (NFC), smart meters, the Internet-of-Things (IoT), cloud computing, relational databases, etc., that together form a smart digital ecosystem that fosters data-driven innovations and supports new business models." [7] (p. 173).

All over the world, governments, local authorities, and private organizations are designing and implementing initiatives in the field of ST. It seems to be the 'new Eldorado' offering significant potential of competitiveness. However, ST plans and initiatives are huge investments and, consequently, require a comprehensive approach and management. Although these plans seem to be a technical issue, underlying it is a fundamental change of thinking on how tourist suppliers shall engage and design 'value propositions' for their customers. That is, the implementation of technological infrastructure has 
to have a soul and serve a strategic purpose [8]. They require long-range planning and well-crafted partnerships and collaborations. An investment in designing, developing, and implementing ST services is a long-term commitment and, consequently, a strategic management decision that requires a thoughtful consideration.

As a result, over the last five or so years scholars have been interested in the field of ST-however, with a special interest and emphasis on exploring related issues at macro/destination level [2]. A screening of the extant literature in this field indicates that academic research is focused on conceptual studies or general studies regarding the main component elements of ST ecosystem [9]. These studies are predominantly focusing on destinations and cities rather than tourist businesses/suppliers, with few exceptions, such as the study by Wang et al. [8]. There is a lack of empirical research on specific contexts and settings in the tourism field, such as hospitality and attractions. Therefore, there is a need for empirical studies on implementation of ST principles at micro-level business/organization.

In addition, in the digitalized and highly competitive business environment, there is a significant financial challenge to address and properly manage the investment in cutting-edge technological infrastructure that is continuously evolving. There is a need to properly manage the ST plans due to the high volume and risk investments. Against this background, this paper attempts to address a research gap. The main research question is stated as follows: "How can the performance of smart tourism plans/initiatives at micro/business level be assessed?" This study addresses this question by suggesting a framework for performance evaluation, based on theoretical backgrounds of Service-Dominant Logic (SDL) and strategic management.

The study's aim is to suggest a framework for performance evaluation of ST initiatives implemented in tourist attractions. The remainder of the paper is structured as follows. Section 2 outlines and discusses the theoretical foundations of study's approach and focuses on the performance evaluation in tourist attractions, as well as the previous studies. Section 3 presents the suggested framework and template, based on the Balance Scorecard (BSC) framework, an established strategic planning and management tool. The research design implemented is discussed in Section 4, presenting the main elements of empirical investigation aiming at testing and validating the suggested template. The last two sections present and discuss the study's findings and conclusion.

\section{Literature Review}

This section outlines and discusses the theoretical foundations of the study, the BSC approach, as well as the previous studies. The focus is on the specific setting/context of performance evaluation of smart initiatives undertaken by tourist attractions.

\subsection{Service-Dominant Logic}

Service-Dominant Logic (SDL) is a valuable theoretical approach and research stance. According to SDL, the companies should focus their energies and resources on bringing together dynamic, specialized competences, knowledge, and skills to create and deliver service, which should be the basis for all business activity [10]. SDL involves a total of ten fundamental principles [11]. One of these fundamental principles is that customers should be treated as operant resources, bringing their skills, experience, and knowledge into the relationship with companies. Value can be created only through this process. Value is co-created jointly and contextually by the company and the customer [12]. Overall, SDL highlights customer-defined and co-created value, operant resources (knowledge and skills) as the fundamental source of competitive advantage, as well as two-way communication with customers and relationship management [13].

These fundamental ideas in marketing are closely related to tourism [14]. The main propositions of SDL and the links between this and related marketing concepts have been explored in the tourism field (see, for instance, $[14,15]$ ). Li [14] suggested that SDL provides a useful theoretical perspective in making sense of marketing practices in the field of tourism destination. In addition, the SDL research stance is considered as a valuable approach to explain the value of co-creation in different tourism 
contexts [16-20]. Within the context of tourism destinations, Wang et al. [21] suggests that SDL can provide an understanding of the process towards value co-creation in smart tourism destinations. In the same vein, the study by Boes et al. [19] argues that SDL approach provides an underpinning for understanding the value co-creation process at the core of every smart initiative. From the same perspective (tourism destination), Femenia-Serra and Neuhofer [4] suggest that ST experiences have four main dimensions that are derived from the technological infrastructure and the close interaction between tourists and the other destination's stakeholders. These dimensions are: data-driven, built in real time, based on context-awareness, and co-created. This conceptualization is the extension and application of fundamental principles of SDL in the smart tourism ecosystem.

Therefore, it can be argued that SDL is central to value co-creation within ST destinations. It is worth pointing out that technology implementation is not sufficient for developing a full ST experience. This technology is a tool and has to be used to perform a dynamic co-creation of the experience for delivering actual value to all the destination stakeholders [4,22]. Boes et al. claim that "destination managers have to acknowledge the multi-facet construct of smartness to create value for all and enhance competitiveness" [19] (p. 120). This opinion is shared by Buhalis and Amaranggana [23].

This issue of co-creation was investigated within the complex environment of tourism destination at macro level $[20,24]$. Nevertheless, one of the key actors and main elements of a ST ecosystem and destination is the smart tourism businesses. Very few studies investigated the issue of co-creation at micro/business level and in specific tourism settings. The pairing between cutting-edge technologies and co-creation for better experiences has been proven successful in the hospitality industry [22]. The study by Wang et al. [8] took the same research stance (SDL) to explore the implementation of smartness in tourism attractions from a consumer perspective.

Tourism attractions and other suppliers of tourism services are not facing the same issues resulting from the complex ecosystem of stakeholders involved in value co-creation at destination level [19]. At business/micro setting, the experience is co-created between service supplier-tourist and tourist-tourist $[4,21]$. The business scale/context is therefore different and requires an adequate approach, as outlined hereafter.

As already indicated, the focus of this study is on performance evaluation. The approach is based on SDL principles and capitalizing and elaborating on extant literature indicating the key elements in this field $[8,18,19,23,25,26]$. It is believed that there are three main pillars/component elements of designing smart services in tourist attractions, namely: value propositions (a strategic management and marketing aim), context and technological infrastructure, and customer/visitor (as co-creator of value. These elements should produce a final output, which is the smart tourism experience $[1,4,5,8]$. The conceptual foundation of assessing the performance is founded on the SDL research stance and consists of the three elements/pillars, as shown in Table 1.

Table 1. Component elements/pillars of implementing a smart system (infrastructure and services) in tourism attractions.

\begin{tabular}{|c|c|}
\hline Component Elements & Content and Description \\
\hline $\begin{array}{l}\text { 1. Strategic management } \\
\text { and marketing aims }\end{array}$ & $\begin{array}{l}\text { - } \quad \text { To improve the efficiency and effectiveness of resource management; } \\
\text { - } \quad \text { To enhance tourism experiences; } \\
\text { - } \quad \text { To meet current and future demands and expectations of consumers; and } \\
\text { - } \quad \text { To design and offer 'value propositions' for the customers/visitors and to engage with them. }\end{array}$ \\
\hline \multirow{6}{*}{$\begin{array}{l}\text { 2. Context and } \\
\text { Technological } \\
\text { infrastructure }\end{array}$} & 2.1 Design and operation: aiming at achieving interaction and engagement: \\
\hline & - $\quad$ All elements should be crafted and designed to offer 'value propositions' to customers/visitors, \\
\hline & Interaction is based on physical/tangible resources and the technological infrastructure. \\
\hline & 2.2 Technologies as enabler /facilitator: \\
\hline & $\begin{array}{l}\text { - Interaction among the two main actors (supplier and customer) is also articulated through a } \\
\text { technological infrastructure composed by smart technologies and services. }\end{array}$ \\
\hline & $\begin{array}{l}\text { These technologies enable a tourist supplier to be 'smart' in terms of generating real-time } \\
\text { intelligence about visitors' needs and wants and responding to them. }\end{array}$ \\
\hline
\end{tabular}


Table 1. Cont

\begin{tabular}{ll}
\hline \multicolumn{1}{c}{ Component Elements } & \multicolumn{1}{c}{ Content and Description } \\
\hline $\begin{array}{l}\text { 3. Customer/Visitor as } \\
\text { co-creator of value }\end{array}$ & $\begin{array}{l}\text { The features of smart tourism (ST) suppliers include co-creation processes, well-connected services, } \\
\text { personalized services, engagement, and efficient communication and management, features that are } \\
\text { entailed by SDL approach and all contribute to co-creation of value. }\end{array}$ \\
$\begin{array}{ll}\text { 4. The final output: Smart } \\
\text { tourism experience }\end{array}$ & $\begin{array}{l}\text { A multi-layered type of experience that is a co-created, data-driven, constructed on a context-aware } \\
\text { and real-time way. }\end{array}$ \\
\hline Source: & Authors' elaboration based on various resources; i.e., $[4,5,8,18,19,23,25,26]$.
\end{tabular}

The above outlined principles and component elements should be applied to designing and implementing smart infrastructure and services in tourist attractions. They should also be the foundation for crafting a performance evaluation approach. As it might be seen, 'value propositions' is a key concept underlying this approach.

\subsection{Value Proposition/s and Value Co-Creation in Tourist Attractions and Destinations}

McKinsey [27] (p. 53) defined the value proposition as "A clear, simple statement of the benefits, both tangible and intangible, that the company will provide, along with the approximate price it will charge each customer." The SDL holds that companies/organizations offer value propositions, that value is co-created during interactions, and that value is subjectively determined by the customer in context, e.g., when the customer uses products or services [11,28]. Hence, value depends on both the interaction and the customer context, not only on the value proposition. Skalen et al. [29] point out the two major aspects of the value proposition concept in SDL, namely, the focus on co-creation and the importance of resource integration.

Value creation refers to the customer being better off when using a product or service; for instance, when on sightseeing using smartphone. To realize the value proposition, a company/organization must co-create value with its customers by means of direct interaction, making the customer feel better, more comfortable $[10,30]$; i.e., instructing the customer in how to use a visit recommender to avoid crowds and queuing while visiting a tourist attraction. The other aspect differentiating SDL is resource integration. The operant resources facilitate companies to make value propositions [31] and are integrated in the configurations that companies offer the market in the form of value propositions [11,32]. In this regard, Skalen et al. [29] suggest that value propositions are "configurations of several different practices and resources" (p. 137).

The topics of value proposition and value co-creation in the context of tourist attractions and destinations were explored by few studies, as outlined hereafter. The study of Rather et al. [33] explores the key antecedents and effects of tourism customer engagement, based on SDL theoretical foundation, within the context of tourist attractions in India. The study's results indicate that (i) there was a positive effect of place authenticity and place attachment on customer engagement; (ii) customer engagement has a positive influence on the development of customer trust, brand loyalty, and co-creation; and (iii) customer engagement has a mediating role in the effect of place attachment and place authenticity on customer trust, loyalty, and co-creation. The study of Cirjevskis [34] considers the customer value proposition as an encapsulation of a strategic management decision on what the organization believes its customers value the most and what it can deliver in a way to achieve a competitive advantage. His study's aim was to develop and test the framework of organizational eco-map to explore how strategically valuable resources are underpinning a new customer value proposition of an organization. Empirically, the paper examines the role of Latvian cultural resources in the transformation of the customer value proposition for Riga Central Market of Latvia, a huge infrastructural establishment. The paper suggests new ways of understanding customers' value creation for a 'slow tourism' destination and proposes the design of marketing strategies to promote effectively cultural resources.

The value and utility of smart technologies in expanding the innovative potential and creative opportunities of tourism suppliers and in creating value propositions for consumers, was the topic 
of two studies. The first study by Serravalle et al. [35] argues that using augmented reality in museums could create engagement, and explores the contribution and uses of augmented reality to increased engagement (through additional digital contents) in visitors' experience in museums from a multi-stakeholder perspective. Their study contributes to a better understanding of value co-creation through the involvement of different stakeholders and their interconnected relationships. Their study also develops theoretical propositions and applications in the field of technology-enhanced customer experience. The second study was performed by Shen et al. [9]. It has the same focus (on tourist attractions) and aims at exploring how smart technologies influence the customer journey. The study takes a consumer behavior perspective with a specific focus on the visit cycle (prospective, active, and reflective phases), based on the theoretical foundations of customer journey process model. The empirical investigation was performed within the setting of the Ningbo Museum, Ningbo, China. This investigation allows to get insights into consumer behavior, which is useful for a tourist attraction to become 'smarter.' The study's findings indicated that smart technologies have an influence on the customer journey at all three phases, the most significant being at the prospective and active phases, without neglecting the reflective one.

A better understanding of the online experiential value co-creation and of the functions of different online co-creation activities is valuable to industry practitioners. A huge amount of user-generated content (UGC) information is now available to tourist consumers on social networking sites. Tourist consumers can access this information to support their decision-making process. This information is also accessible freely and generates open data to be used by tourism destinations and suppliers for business purposes. The study by Pantano et al. [36] investigates the extent to which open data analyses might predict tourists' response to a certain destination based on profile characteristics. Their study suggests a process of predicting tourists' future preferences by analyzing open data (tourists' reviews) that are available on social media. It also devises the classification function and the best model for predicting the destination tourists would potentially select. The procedure is practicable and useful for attractions and tourism destinations. The study of Fan et al. [37] explores tourists' experiential value co-creation through online social contacts by adopting a customer-dominant logic. The study suggests three distinct values/factors, i.e., intrinsic/extrinsic enjoyment, logistics, and efficiency values. It was found that all three distinct values were created online during travel. It is believed that the proposed measurement scale would assist industry practitioners in assessing the effectiveness of different online activities and monitoring the progress toward identifying and creating positive experiential value for tourists.

Other issues related to tourist attractions and destinations, such as customers' experience, cooperation, and evaluation of smartness, were also explored by previous studies. The study by Gao et al. [38] examines how a memorable experience is created by many thematically linked destination attributes that come together to involve and create value for customers within the context of Zhouzhuang, a popular Chinese water town. It was found that destination attributes are associated with different themes which provide different types of customer value. Ali et al. [39] proposes a model to assess visitor experiences at Malaysian theme parks with the aim to investigate the interplay between customer experience and emotions within the specific context. Their study examines the visitor experience and its effect on their delight, satisfaction, and loyalty. It was found that physical setting, interaction with staff, and interaction with other customers had a significant impact on both customer delight and satisfaction.

The study by Wang et al. [8] is the only one that addresses the issue of evaluation in the context of smart tourist attractions. Their study performs a quantitative evaluation of these attractions by identifying tourist preferences and suggests a set of 28 key evaluation items. The issue and challenge for tourist attractions is to make an optimal use of facilities and infrastructure by offering suitable value propositions. It is believed that the study by Wang et al. [8] is a valuable contribution in the sense that it points out the imperative for ST projects to have a tourist-centric approach.

The above outlined studies extended our knowledge by providing new insights into the topic of value proposition, value co-creation, and the influence of smart technologies on them. Nevertheless, 
the topic of performance evaluation in tourist attractions has not been explored and investigated by scholars. As already highlighted (see Table 1), the two business strategic aims are (i) to improve the efficiency and effectiveness of resource management, and (ii) to enhance tourism experiences. The business performance and progress towards achieving these two aims should be monitored and evaluated systematically. It is the argument of our study that the BSC is a suitable framework to provide a strategy map and assess the performance. It constitutes a framework contributing to explore and elicit Critical Success Factors (CSFs) and indicators in performance measurement. This is the issue of the following subsection.

\subsection{Performance Evaluation: The Balanced Scorecard Approach}

The BSC approach provides a framework that enables a company's management to describe their strategy in a reliable manner. The BSC is a strategic management framework that companies/organizations use to (i) communicate what they are trying to accomplish; (ii) align the day-to-day work that everyone is doing with strategy; (iii) prioritize projects, services, and products; and (iv) measure and monitor progress towards strategic aims [40,41]. It is based on the balance between leading and lagging indicators, which can respectively be thought of as the drivers and outcomes of the company's aims. The ultimate goal behind the BSC approach is to measure the factors that create value for a company/organization and directly influence its ability to prosper. BSC is therefore a strategic management framework that maps a company's strategic objectives into performance measures; it 'balances' four critical perspectives within a company/organization, namely: financial, customer, internal process, and learning and growth [40,42].

The BSC has been widely adopted by manufacturing, service, non-profit, and public organizations around the globe [42-44]. The term BSC reflects Kaplan and Norton's [45] attempt to provide a monitoring system that communicates both financial and nonfinancial measures using a combination of lagging and leading indicators while addressing long-term and short-term objectives [46]. BSC has emerged as a valuable tool for performance management, a tool that provides managers with the mechanisms to develop performance targets and indicators linked to strategy [42].

Literature suggests that business success can best be achieved and assessed when regarded in systematic way from four perspectives: financial, customer, internal business processes, and innovation/learning and growth (see Table 2). Moreover, the effective implementation of BSC contributed to developing strategic thinking, teamwork, and learning [46]. The BSC ties each question that represents a corporate objective to an outcome measurement. The outcome measurement-a 'lagging indicator' - measures what has happened, while a driver measurement-a 'leading indicator'-looks at the potential to improve performance [47]. Ziegenfuss [48] suggests that there should be a maximum of 10 indicators, across the four perspectives, to avoid the process becoming unwieldy. By so doing, a company avoids assessing secondary indicators and can dedicate its capacities and resources on important activities [45,49].

Table 2. Balance Scorecard: Four Perspectives of Organizations' Strategy, Content, and Factors.

\begin{tabular}{lll}
\hline Perspectives & \multicolumn{1}{c}{ Main Issue and Content } & \multicolumn{1}{c}{ Factors } \\
\hline & $\begin{array}{l}\text { In commercial/for-profit organizations it contains the } \\
\text { financial outcomes and the results of what the } \\
\text { organization costs and the revenues that the customers } \\
\text { provide. }\end{array}$ & Lagging factors acting as a system of checks. \\
& $\begin{array}{l}\text { In no-profit organizations, it contains sources of income } \\
\text { (e.g., donations, subsidies) as opposed to customer } \\
\text { sources revenue. }\end{array}$ & \\
\hline & $\begin{array}{l}\text { "How should the organisation appear to its customers?" } \\
\text { A clear and accurate image of what customers really } \\
\text { 2. Customer } \\
\text { want (not what management thinks they want); e.g., }\end{array}$ & $\begin{array}{l}\text { Indicators to capture customer opinion; e.g., customer } \\
\text { satisfaction of customers. }\end{array}$ \\
\hline
\end{tabular}


Table 2. Cont.

\begin{tabular}{|c|c|c|}
\hline Perspectives & Main Issue and Content & Factors \\
\hline $\begin{array}{l}\text { 3. Internal } \\
\text { Processes }\end{array}$ & $\begin{array}{l}\text { "To satisfy its stakeholders and customers, what business } \\
\text { processes must organisation excel at?" } \\
\text { Need for meaningful objectives for the processes. Ensure } \\
\text { that these processes support the customers goals and the } \\
\text { financial goals. Example: innovative processes. }\end{array}$ & $\begin{array}{l}\text { What should we do to meet customer needs? } \\
\text { Non-financial indicators to measure quality. }\end{array}$ \\
\hline $\begin{array}{l}\text { 4. Learning, } \\
\text { Innovation and } \\
\text { Growth }\end{array}$ & $\begin{array}{l}\text { "How will the organisation sustain its ability to change } \\
\text { and improve?" } \\
\text { The wide range of drivers of capability in the } \\
\text { organization. }\end{array}$ & $\begin{array}{l}\text { Ensure continuous efforts to delight and retain } \\
\text { customers. The focus should be on the future capabilities. } \\
\text { Indicators related to new product development, process } \\
\text { improvement and human resource skills. }\end{array}$ \\
\hline
\end{tabular}

In practice, BSC is a systematic approach to monitor performance and is mainly used for self-assessment. The four core perspectives, as outlined in Table 2, are linking business strategies and visions to individual aims and measures [44]. Measures or Indicators help management understand if they are accomplishing their aims strategically. A company might have one to two measures per aim [44].

The results of a study by Phillips and Louvieris [42] illustrated that BSC processes are appropriate in tourism related industries. They identified four priority factors-budgetary control, customer relationship management, strategic management, and collaboration - that are slightly different from four perspectives suggested by Kaplan and Norton [40,41]. Their study's results illustrated how companies can adopt the BSC to achieve a flexible approach to adapt the management framework to their context and requirements. The study by Gallo et al. [49] formulates the same suggestions, pointing out that BSC is a management tool supporting the performance evaluation and continuous improvement of business processes.

The above discussion highlights that the issue of evaluation in general and of performance evaluation in particular are under researched. Very few studies have been performed in this field. There is a need for more conceptual and empirical research within the context of ST management framework [1,9]. Our study attempts to address a knowledge gap in this field. The main argument is that tourist attractions must implement the suitable tools in assessing their performance.

\section{Suggesting an Evaluation Framework: A Balance Scorecard Template}

This study argues that it is possible to elaborate and suggest an evaluation tool for the performance measurement in tourist attractions founded on theoretical backgrounds outlined in Section 2 (SDL approach) and applying the BSC management framework. As it can be seen, there is a common denominator to the two above outlined theoretical and management frameworks; that is the 'value proposition.' This concept is central to SDL, BSC, and to the suggestions formulated by Wang et al. [8]. This is equally the starting point of our suggestion and underlying principle of all management and marketing functions and processes of a Smart Tourist Attraction (STA) $[4,21,50,51]$.

Firstly, this study suggests the following definition for STA, based on the extant literature [1,5,19,52]. A smart tourist attraction is defined as "the tourism business/organization that (i) explores and understand the tourist consumers' preferences and expectations; (ii) implements smart projects/initiatives to offer service and value propositions to its visitors with the aim to providing them with interesting and memorable experience opportunities; (iii) systematically evaluates its performance in this field, and (iv) seeks for continuous improvement of smart services and value propositions." This description was mainly based on definitions proposed by Buhalis [51] and Koo et al. [52] about the STDs.

Smart projects have two key aims, namely, (i) to offer high quality value propositions to connected and engaged tourists that dynamically interacting with the company/supplier, and (ii) to co-create tourism services and add value for all to share. Tourism companies/suppliers, individually and collectively at destination level, provide tourists with real-time and personal services, and simultaneously collect data for the optimization of their management; in other words, improve their 
effectiveness $[1,21,51]$. Therefore, it could be argued that there are four key elements to consider and incorporate into an evaluation framework, namely: (i) Strategic aims, which are to delight visitors and improve business performance; (ii) Plan and means, which are the smart infrastructure and technologies; (iii) Offering, which is the smart services and value propositions to customers; and (iv) Final outcome, the co-creation of high-quality and memorable experience, as outlined in Table 1.

Therefore, tourist attractions should adopt a rational and structured approach with the aim to evaluate their performance and outcomes in the field of strategic management and marketing. In simple terms, a BSC template is how a company (e.g., a tourist attraction) structures a strategy map to communicate its plans and intentions. The performance should be measured and outcomes should be assessed. It is worth indicating that simply having a BSC does not help execute the strategy; the company has to actually implement the strategy. The BSC framework should hold every manager/head of department accountable for being timely and accurate, report regularly, and proceed to necessary modifications, if needed. It will then be highly useful and valuable.

The suggested template (depicted in Table 3 ) is based on the above discussion and resulted from an adaptation and extension of a BSC template for the hotel industry, suggested by Phillips and Louvieris [42].

Table 3. Suggested BSC Template for Tourist Attractions (private- and public-run).

\begin{tabular}{|c|c|c|}
\hline Perspective & Critical Success Factors & Key Performance Indicators \\
\hline \multirow[t]{3}{*}{ Financial } & $\begin{array}{l}\text { Profitability } \\
\text { Increase Shareholder Value }\end{array}$ & $\begin{array}{ll}\text { - } & \text { Revenue/Volume of sales } \\
\text { - } & \text { Expenses (as \% of Sales) } \\
\text { - } & \text { Operating profit } \\
\text { - } & \text { Expand and diversify sources of revenue } \\
\text { - } & \text { Costs management (Efficient use of } \\
& \text { financial resources) }\end{array}$ \\
\hline & $\begin{array}{l}\text { Budgetary control (as a means of } \\
\text { controlling and monitoring performance) }\end{array}$ & $\begin{array}{l}\text { - } \quad \text { Adhering to budget and meeting targets } \\
\text { - } \quad \text { Spending/expenditure per visitor }\end{array}$ \\
\hline & Accountability and Transparency & - $\quad$ Auditing and Reporting (reports) \\
\hline \multirow[t]{3}{*}{ Customer } & $\begin{array}{l}\text { Quality of service and Customer } \\
\text { satisfaction }\end{array}$ & $\begin{array}{l}\text { Measures to capture customer's opinion: } \\
\text { - } \quad \text { Visitor experience surveys } \\
\text { - } \quad \text { Quality of services (efficiency): response time } \\
\text { - } \quad \text { Perception about value for money } \\
\text { - } \quad \text { Complaint rate } \\
\text { - } \quad \text { Customer satisfaction levels } \\
\text { - } \quad \text { Customer retention rate and recommendation rate }\end{array}$ \\
\hline & Customer relationship management & $\begin{array}{l}\text { Handling comments and complaints on Social Media } \\
\text { - } \quad \text { Online reviews } \\
\text { - } \quad \text { Online reputation management }\end{array}$ \\
\hline & Managing Donors and Volunteers & $\begin{array}{l}\text { - Support local business and workforce needs } \\
\text { - } \quad \text { Reward donors and volunteers (through } \\
\text { Loyalty/Membership and Reward/Incentive plans) }\end{array}$ \\
\hline \multirow[t]{2}{*}{$\begin{array}{c}\text { Internal } \\
\text { Processes }\end{array}$} & Systems and Processes & $\begin{array}{l}\text { - } \\
\text { - } \\
\text { Efficiency in terms of time (response time } \\
\text { and deadlines) } \\
\text { - } \\
\text { - } \\
\text { - } \\
\text { Participibility in terms of personalion in grading schemes } \\
\text { Accreditation/Certification schemes }\end{array}$ \\
\hline & Investing in human resources & $\begin{array}{l}\text { - Staff development plans (seminars, workshops, and } \\
\text { other learning forms) } \\
\text { - } \quad \text { Level of staff satisfaction and staff retention rate (in \%) } \\
\text { - } \quad \text { Productivity (staff/turnover) }\end{array}$ \\
\hline
\end{tabular}


Table 3. Cont.

\begin{tabular}{|c|c|c|}
\hline Perspective & Critical Success Factors & Key Performance Indicators \\
\hline \multirow{2}{*}{$\begin{array}{l}\text { Innovation/ } \\
\text { learning }\end{array}$} & $\begin{array}{l}\text { Developing organisation future } \\
\text { capabilities and human resources skills } \\
\text { and competencies }\end{array}$ & $\begin{array}{l}\text { - } \\
\text { - } \\
\text { - } \\
\text { - } \\
\text { - } \\
\text { Investments in Reser of new initiatives for process improvement } \\
\text { and interdisciplinary) } \\
\text { - } \\
\text { - } \\
\text { Lttract funding (for research and other purposes) } \\
\text { innovation and change }\end{array}$ \\
\hline & $\begin{array}{l}\text { Collaboration to drive innovation and } \\
\text { learning }\end{array}$ & $\begin{array}{l}\text { - } \quad \text { Collaborative and high-achieving environment } \\
\text { - } \quad \text { Benchmarking/Cross-industry comparison } \\
\text { - } \quad \text { Networking (Alliances, partnerships, national } \\
\text { and international) } \\
\text { - } \quad \text { Number of best practices adopted and implemented. } \\
\text { - Sustainable action plans: number of plans } \\
\text { supported and/or implemented }\end{array}$ \\
\hline
\end{tabular}

Note: In bold are highlighted the elements/items that are suggested additionally for Public-run Tourist Attractions to those proposed for Private tourist attractions.

It is the argument of this paper that BSC provides the suitable framework for performance evaluation, having the additional characteristic of being a flexible tool that permits to take into account the particularities of tourist attractions. The above BSC template was tested through an empirical study whose main elements are presented in the following section.

\section{Materials and Methods}

\subsection{Methods}

Data collection was performed in two stages. In the first stage, an interview plan was drafted based on the suggested BSC template for tourist attractions and input collected from industry experts and practitioners. To identify the specific areas, a preliminary investigation into the critical success factors (CSFs) in tourism attractions was conducted by interviewing 10 experts, academics, and managers. Interviewees were asked to provide their input and ideas to improve the content of suggested template.

Based on their input, the research instrument (interview plan) was improved. This interview plan was further improved (in terms of consistency and coherence) and finalized based on the feedback from a pilot study; that is, interviews conducted with the managers of three tourist attractions. Some points of the interview plan were accordingly revised to attain better accuracy. The outcome was the final version of the interview plan, which was then translated into Chinese language (the English version is provided in Supplementary Material).

Second, individual semi-structured interviews were conducted with the managers of selected tourist attractions. This method was followed by content analysis. Semi-structured interview was chosen as a research instrument because the study's aim was to analyze the managers' perceptions upon a specific issue and its aspects $[53,54]$. This research approach was adopted by other related studies, see, for instance $[8,26]$.

Given the exploratory nature of the investigation, the suggested BSC template was used as a descriptive framework. Interviewees/participants were asked about the CSFs included in the four perspectives and the corresponding Key Performance Indicators (KPIs). The interview plan consisted of the following seven sections: (1) Tourist attraction information; (2) Concepts and Suggested BSC template; (3) Opinion about Perspective No 1-Financial; (4) Opinion about Perspective No 2-Customer/Visitor; (5) Opinion about Perspective No 3-Internal Processes; (6) Opinion about Perspective No 4-Innovation \& Learning; and (7) Specific/additional CSFs and KPIs. The participants 
were asked to rate the importance using a five-point Likert-type scale $(1=$ not at all important, $5=$ very important) and value/utility ( 1 = not at all useful, 5 = very useful).

In total, 30 interviews with managers of selected tourist attractions were conducted in April and May 2020 to capture their opinion about the performance evaluation and the suggested BSC template. The interviews were conducted by one member of the research team following an appointment. Each interview lasted $60 \mathrm{~min}$ in average; all were typed and fully transcribed for data analysis.

\subsection{Study Area and Sample Selection}

Zhejiang Province, People's Republic of China, was selected as the study area. Zhejiang is an eastern, coastal province of China and its capital, and its largest city is Hangzhou. The population of Zhejiang stands at 57 million, the 10th highest among China. Other notable cities include Ningbo and Wenzhou [55]. It has been called 'the backbone of China' due to being a major driving force in the Chinese economy. Zhejiang has grown to be considered one of China's wealthiest provinces, ranking fourth in GDP nationally and fifth by GDP per capita, with a nominal GDP of CN¥5.62 trillion (US\$849 billion) as of 2018 [56].

Zhejiang was among the pioneer provinces in China in implementing ST, the first projects having been launched in 2012. Since then, various events and projects have been performed, such as an exhibition, conference, a web portal 'Zhejiang Smart Tourism,' and a pilot ST project in 27 tourism-related companies. Currently, Zhejiang undertakes more innovative practices in the field of ST [57]. It is reported that additionally to various ST management and guiding systems for attractions, Zhejiang Provincial Administration also established a cloud data center for tourism. This project encompasses collection, storage, and processing systems to achieve connection and data sharing for management decision-making.

The 30 tourist attractions selected for the empirical study are located in various departments of Zhejiang Province. Their choice was made based on four criteria, namely: (i) Rated grade 4A and 5A by the China National Tourism Administration (Tourist attractions or scenic areas rated as $5 \mathrm{~A}$ are the most important and best-maintained tourist attractions in the People's Republic of China, given the highest level in the rating categories used by the Ministry of Culture and Tourism); (ii) Implementation of smart tourism projects/initiatives over the last five years; (iii) Volume of visitation; and (iv) Type of ownership and management (private and public) as well as their type (cultural, natural, and other) to obtain representativeness of sample. Based on the above four criteria, the research team chose 30 tourist attractions to conduct the semi-structured interviews.

The following table (Table 4) depicts the general information about tourist attractions, encompassing a code name for the interviewed manager in order to keep their anonymity.

Table 4. Interviewees and profile of Tourist attraction-Information.

\begin{tabular}{ccccccc}
\hline No & $\begin{array}{c}\text { Interviewees' } \\
\text { Code }\end{array}$ & Gender & $\begin{array}{c}\text { Type of } \\
\text { Attraction }\end{array}$ & Category & $\begin{array}{c}\text { Ownership/ } \\
\text { Management }\end{array}$ & $\begin{array}{c}\text { Investments in } \\
\text { Smart Projects } \\
\text { (Last 5 Years in } \\
\text { Yuan) }\end{array}$ \\
\hline 1 & BN & Male & Natural & $5 \mathrm{~A}$ & Public & $>2$ million \\
\hline 2 & GC1 & Female & Cultural & $5 \mathrm{~A}$ & Private & $>2$ million \\
\hline 3 & CA & M & Amusement park & $5 \mathrm{~A}$ & Private & $>2$ million \\
\hline 4 & JC & M & Cultural & $5 \mathrm{~A}$ & Public & $0.5-0.8$ million \\
\hline 5 & GN1 & F & Natural & $4 \mathrm{~A}$ & Private & $0.8-1$ million \\
\hline 6 & ZN & M & Natural & $4 \mathrm{~A}$ & Private & $0.5-0.8$ million \\
\hline 7 & SN & M & Natural & $5 \mathrm{~A}$ & Public & $>2$ million \\
\hline 8 & ZC & M & Cultural & $4 \mathrm{~A}$ & Public & $1-2$ million \\
\hline 9 & XN1 & F & Natural & $5 \mathrm{~A}$ & Private & $>2$ million \\
\hline
\end{tabular}


Table 4. Cont.

\begin{tabular}{|c|c|c|c|c|c|c|}
\hline No & $\begin{array}{l}\text { Interviewees' } \\
\text { Code }\end{array}$ & Gender & $\begin{array}{c}\text { Type of } \\
\text { Attraction }\end{array}$ & Category & $\begin{array}{l}\text { Ownership/ } \\
\text { Management }\end{array}$ & $\begin{array}{c}\text { Investments in } \\
\text { Smart Projects } \\
\text { (Last } 5 \text { Years in } \\
\text { Yuan) }\end{array}$ \\
\hline 10 & $\mathrm{BC}$ & $\mathrm{F}$ & Cultural & $5 \mathrm{~A}$ & Public & 1-2 million \\
\hline 11 & $\mathrm{CN}$ & $\mathrm{M}$ & Natural & $5 \mathrm{~A}$ & Private & $>2$ million \\
\hline 12 & LC1 & $\mathrm{F}$ & Cultural & $4 \mathrm{~A}$ & Private & $<0.25$ million \\
\hline 13 & $\mathrm{HC}$ & $\mathrm{F}$ & Cultural & $4 \mathrm{~A}$ & Private & $0.25-0.5$ million \\
\hline 14 & WA1 & M & Amusement park & $4 \mathrm{~A}$ & Public & $0.5-0.8$ million \\
\hline 15 & GN2 & $\mathrm{F}$ & Natural & $4 \mathrm{~A}$ & Private & 0.8-1 million \\
\hline 16 & $\mathrm{HN}$ & $\mathrm{M}$ & Natural & $5 \mathrm{~A}$ & Private & $>2$ million \\
\hline 17 & LC2 & $\mathrm{F}$ & Cultural & $5 \mathrm{~A}$ & Public & 1-2 million \\
\hline 18 & LC3 & M & Cultural & $5 \mathrm{~A}$ & Private & $>2$ million \\
\hline 19 & WN & $\mathrm{F}$ & Natural & $4 \mathrm{~A}$ & Public & $<0.25$ million \\
\hline 20 & WC1 & $\mathrm{M}$ & Cultural & $4 \mathrm{~A}$ & Private & $0.25-0.5$ million \\
\hline 21 & QN & $\mathrm{F}$ & Natural & $4 \mathrm{~A}$ & Public & $0.5-0.8$ million \\
\hline 22 & $\mathrm{XC}$ & M & Cultural & $4 \mathrm{~A}$ & Private & 0.8-1 million \\
\hline 23 & GC2 & $\mathrm{M}$ & Cultural & $5 \mathrm{~A}$ & Private & $>2$ million \\
\hline 24 & LA1 & $\mathrm{F}$ & Amusement park & $5 \mathrm{~A}$ & Public & 1-2 million \\
\hline 25 & GC3 & $\mathrm{M}$ & Cultural & $5 \mathrm{~A}$ & Private & $>2$ million \\
\hline 26 & WA2 & $\mathrm{M}$ & Amusement park & $5 \mathrm{~A}$ & Public & $1-2$ million \\
\hline 27 & $\mathrm{RC}$ & $\mathrm{F}$ & Cultural & $5 \mathrm{~A}$ & Private & $>2$ million \\
\hline 28 & XN2 & $\mathrm{F}$ & Natural & $4 \mathrm{~A}$ & Public & $<0.25$ million \\
\hline 29 & WC2 & $\mathrm{F}$ & Cultural & $4 \mathrm{~A}$ & Private & $0.25-0.5$ million \\
\hline 30 & LA2 & $\mathrm{F}$ & Amusement park & $5 \mathrm{~A}$ & Public & $>2$ million \\
\hline
\end{tabular}

It is believed that the above sample was representative; interviewees were from 30 tourist attractions of different type and ownership/management. More specifically, managers were evenly distributed in terms of gender (50\% male and 50\% female). As for the type, $11(36.7 \%)$ are natural, 14 $(46.7 \%)$ cultural, and $5(16.6 \%)$ are amusement parks. The 17 attractions $(56.7 \%)$ rated grade $5 \mathrm{~A}$ and the other $13(43.3 \%)$ are rated grade $4 \mathrm{~A}$. As for the type of ownership/management, the distribution is 13 public-run and 17 private-run attractions. The investments in smart projects over the last five years varied between 0.25 million to more than 2 million yuan (RMB), the largest segment was the that over 2 million, followed by the attractions having invested between 1 and 2 million.

\section{Results: Data Analysis and Findings}

This study adopted the content analysis (based on Grounded theory) to conduct the 2-levels data analysis, encoding, and processing. At first level, the research team conducted the pre-processing of data, encoding all interviews in order to process collected data. Then, at second level, data were processed, using content analysis and key words to classify the data with the aim of discussing the various related issues and aspects. The key elements of data analysis are presented and discussed in the following points per issue, following the sequence of the interview plan (presented in Supplementary Material).

\subsection{Concepts: Value Propositions and BSC Framework}

Value propositions: The interviewees agree that the value is decided by the visitors when they visit the tourist attraction. BN indicated that "Visitors come to our park and buy commodities which 
can bring the income ... the measures we took are exactly the expressions of value propositions." Value propositions are value creation promises created by the organization along with the customers, indicated by QN. Almost all interviewees share the opinion that the value propositions are configurations of practices and resources.

Balance Scorecard (BSC): The approach and tool are considered by the majority of managers as very useful in evaluating the performance in tourist attractions. ZN pointed out that "I know this concept from the business management, I am sure that it is very useful."

\subsection{Opinions about BSC-Financial Perspective}

CSFs in Financial domain/field: According to interviewees' opinion, 'Profitability' is a very important factor, not only for private but also public tourist attractions. LC2 summarizes the perception of all, indicating that "all attractions must be profitable to attain financial sustainability; therefore, they need funding to support their operation and make investments." 'Increase Shareholder Value' is not important factor, the main point being to increase the value of attraction. One manager indicated that "value is not the same concept as money, value increasing means the promotion/boosting of the brand reputation."

'Budgetary control': No matter the size or the type of tourist attraction, budgetary control is a very important factor. "Budgetary control is necessary, it indicates the clear process of the operation condition, but actually our control level is not in accordance with the plan," BN states.

'Accountability and Transparency': Managers have the opinion that this factor is not important. They think it is not a priority; they estimate that budgetary implementation and control is a sufficient and pertinent factor. The same perception stands for 'Reporting'. The interviewees think that this factor is also not important or useful. "It is pointless; even if we do report, no one would pay attention to ..." " A large proportion of interviewees exhibited a disagreement on adopting this factor in performance management.

Key Performance Indicators (KPIs) in Financial domain: 'Revenue/Volume of Sales': All the interviewees expressed their agreement on this KPI; they believe that this indicator is a very important measure. For instance, GC1 highlighted that "Every day we try our best to attract as much tourists as possible. We implement many promotional policies to attract visitors. The longer lasts their visit visitors in the park, the more revenue and sales can be achieved on other services such, as food, transportation, souvenirs, etc. even if the entrance is free." GC1 thinks that this indicator is the key, the most important financial factor. The same interviewee (GC1) indicates that the volume of smart tourists in tourist attractions has been increasing over the last five years, boosted by the investment. The first interviewee (BN) doesn't share the same opinion. In his opinion, "the challenge is to attain a balance/compromise between the financial requirements (i.e., more visitors, higher revenue to improve infrastructure and services) and the preservation of natural environment (mitigating the negative impact of increased visitation)." The main issue is, in his opinion, how to use the revenue (i.e., in protecting/preserving the natural protection at tourist attractions).

Interviewed managers did not consider 'Expenses (as \% of sales)' as being a key indicator in the performance evaluation. On the contrary, they believe that the KPI 'Operating Profit' is very important. They are very straightforward, indicating that "operating profit can reflect the successful operation and determine sustainable future," as stated by CA. Managers' opinion is that the indicator 'Adhering to budget and meeting targets,' is meaningless because it is coming along with other indicators.

Additionally to the KPI 'Revenue and the volume of sales,' the majority of interviewees pointed out that 'Spending/expenditure per visitor' is an important indicator. RC stated: "We have many stores in the park selling many items and souvenirs, the spending by visitor is very important source of revenue; stores are providing a critical stream of income. They make a contribution to profitable operation; therefore, monitoring this indicator is very important." Some interviewees insisted that the income can be invested in improving the smart infrastructure of tourist attractions. 
The indicator 'Expand sources of revenue' is regarded as an important KPI. An interviewee (WC1) claimed that "we should focus on the main core and at the same time put higher volume of efforts in enlarging our revenue sources." Therefore, it constitutes an important financial indicator. The interviewees share the same opinion about KPI 'Costs management,' the management efforts should be oriented simultaneously in managing costs (due to the high volume of fixed costs) and expanding income for both public and private-run attractions. On the contrary, the participants believe that the indicator 'Auditing and Reporting' is not important to monitor.

\subsection{Opinions about BSC—Customer/Visitor Perspective}

CSFs: Three CSFs were under consideration in this perspective. The first, 'Quality of service and Customer satisfaction,' was considered by all interviewees as the most important factor, stating, "Let every visitor feel at home." They considered that this performance area plays a critical role in successfully managing a tourist attraction. Nearly all the interviewees agreed on the statement by WA2, "We eagerly welcome the visitor ... all our actions are visitor-oriented and -centered," echoing the perception of all managers. This opinion is also valid for the second CSF 'Customer relationship management' (CRM). "Manage the relationship with the customer is another way to attract the customer and attain repeat visits," BN said. "In my opinion, it is as important as the customer satisfaction, and to some extent, they are aspects of the same issue, looking after our visitors and maintaining relationship with them." Most of the interviewees indicated that they have a specific department and staff to deal with Guests relations and CRM. This area has the potential of multiple tangible and intangible benefits.

As for the third CSF, 'Managing Donors and Volunteers,' all interviewees did not think it is an important factor. "We don't have donors, our attraction is not a temple, maybe a temple could attract some donors ... " BC said. "Volunteers seldom come to my park, because we can't provide suitable atmosphere and opportunities ... " In their perception, it is impossible to have donors. GC1, who runs a private park, said, "We don't have the support from the government and don't have any donation like other countries..."

KPIs: A series of KPIs were suggested. First, the indicator 'Visitor experience surveys' was regarded by all interviewees as a good way to monitor visitors' opinion and perception. All tourist attractions implement mechanisms for customer feedback and set ways/media (a printed form or some smart equipment or scan the QR code, random calls) to let visitor comment on their experience. One interviewee (CA) claimed that "We need visitor experience survey, but we can't afford the time and energy to conduct that" ... "We do need the survey to monitor visitors' satisfaction, but sometimes it is still difficult to carry out visitor surveys."

'Quality of services (efficiency): response time': "It is useful to measure whether the service quality is good or not," JC said. "Service quality cannot be strictly measured by the indicator 'Response time,' because it needs many means to support it, such as smart equipment." As for the measure 'Perception about value for money,' interviewees believed that it is an important indicator, combined with others. "I think this indicator can be combined with the visitor experience surveys, only then it makes sense," said ZN, adding that he prefers to have feedback from visitors or from online travel agents (OTAs); however, this indicator can't be measured separately. The same perception stands for 'Customer satisfaction levels,' an important indicator; however, it should be implemented along with others (for instance, 'Visitor experience survey').

'Complaint rate': SN indicated that "it is the most essential indicator in performance of tourist attraction"... "Visitors can complain not only to ourselves but also to the supervising authorities/bodies and to the media (traditional and online). We can't interfere with their behavior; however, we have to handle with ... " XN1 said, "No matter how rude the visitor is, if the complaint rate increases, we will face operational problem, we need to dedicate more time and higher volume of efforts to monitor this indicator."

"I think the customer retention rate and recommendation rate are different indicators, we cannot put them together." LC1 stated. "Customer retention rate means the customer is satisfied with the 
experience and will come back, but the recommendation rate is different. The customer might be satisfied with the experience' however, he/she doesn't want to share the experience." Most of the interviewees shared the same opinion; customer retention rate is an important indicator and should be separate indicator.

Regarding the indicator 'Handling comments and complaints on Social Media,' WA1 said “... can put this indicator along with the previous one (the complaint rate), in my opinion, the 2 indicators are very similar." He added: "positive comments are always welcome, but we cannot make comments on social media because visitors would think that they are written by ourselves. As for the negative comments, we handle them the same way the complaints." Most of the interviewees did not think it is necessary to have a separate indicator 'Online reputation management.' The latter can be combined with other indicators, such as 'Complaint rate' and 'Handling comments and complaints on SM.'

'Support local business and workforce needs': "We never think about that," GN2 argued, "every business can support local business; however, I do not consider it is necessary to monitor such an indicator." They have the same opinion about the indicator 'Reward donors and volunteers,' which was regarded as not important in the performance evaluation at all.

\subsection{Opinions about BSC-Internal Processes Perspective}

CSFs: In this field, two CSFs were considered. First, 'Systems and Processes,': interviewees believed that having clear systems and processes is important for every tourist attraction since they have many departments to perform various tasks. It can improve efficiency and cooperation between departments. All managers indicated that this indicator is useful. "Our park is not very large and daily operation is performed by a small group of persons, each of them playing at least 3 roles. So, all processes must clear and precise," WC1 said. This is even more important for big-sized attractions rated grade $4 \mathrm{~A}$ and $5 \mathrm{~A}$, as indicated by interviewees. Second, regarding 'Investing in human resources,' it was stated that human resources are one of the key elements of tourist attractions. "It is necessary to have this indicator to incite/motivate manager and head departments to pay attention to the staff."

KPIs: All managers agreed on the high importance of the KPI 'Reliable, clear and precise procedures. "If the procedures are reliable, clear and precise ... I am sure the other indicators, like complaint rate, visitors' satisfaction level as well as the retention rate, will also perform well." "Our park has reliable and clear procedures, but it is hard to measure precisely, since not all procedures cannot be determined very precisely. Therefore, we have to be adaptive and flexible," QN said. 'Efficiency in terms of time' is another important indicator. LA2, manager of a public attraction for 10 years, considered it necessary to have this indicator in monitoring performance. Especially in a public park, staff is not always efficient ... the result is that the job or business becomes ineffective, unresponsive. "Why should I do more job? I can do it tomorrow; staff members use to say ..." Therefore, this indicator is indispensable in order to avoid such an attitude.

As for 'Flexibility in terms of personalization/customization,' interviewees did not think that this indicator is important. "Personalization and customization are good and valid in the travel agency industry," WC2 said. "In tourist attractions, we do not need flexibility and do not have resources to develop customized products to meet the requirements of different visitors." It could be argued/concluded that the higher rank of the tourist attraction is, the less attention management pays to personalization or customization; their main concern is standardization. Interviewees had the opinion that 'Participation in grading schemes' constitutes an essential indicator. "Grading schemes are necessary, provide guidance and direction to staff members," XN2 said. The same manager added that the next indicator 'Accreditation/Certification schemes' is the same in practice. RC expressed a different opinion, indicating that "Accreditation/certification is necessary to measure the staff performance, on one hand; it can contribute to the implementation and achievement of continuous improvement of quality, on the other hand." She added that there is another potential benefit; it could contribute to the development of staff skills. 
The majority of interviewees expressed their agreement on the importance of the indicator 'Staff development plans,' they believed that this is a very useful indicator for performance management. "Staff is at the core of tourist attraction's management ... We should encourage our staff to further study and improve their skills ... we should provide them with better opportunities and environment in order to get the latest knowledge and know-how," GC3 mentioned. 'Level of staff satisfaction and staff retention rate' was seen as important indicator. Staff satisfaction is another way to demonstrate the service quality in tourist attractions. "Staff may be satisfied with the promotion, benefits, opportunities provided by the management ... it is mainly about caring, looking after our collaborators," WA2 said.

A large proportion of interviewees believed that the indicator 'Productivity (staff/turnover or volume of visitors)' seems to be a repeat. "Productivity is a concept including the staff/turnover compared with volume of visitors ... I think all of them can be put with the corresponding indicator," GC3 said. Therefore, it is not an important KPI.

\subsection{Opinions about BSC—Innovation \& Learning Perspective}

CSFs: Under this perspective, two KPAs were suggested. First, 'Developing organization future capabilities and human resources skills and competencies.' "We should have a clear developing plan and can proceed step by step ... the skills and competencies are necessary to build a better and sustainable future. So, innovation and learning are a very important indicator," LA1 said. "Only a tourist attraction that develops other businesses, will have a bright future ... What we need is the staff who has full energy and competencies to take part in the construction of the tourist attraction," was indicated by another interviewee. Second, regarding the factor 'Collaboration to drive innovation and learning,' GC2 argued that "collaboration is in everything; we should jointly work with others in harmonious manner. One attraction or manager cannot handle everything, innovation and learning require very good cooperation and collaboration; these are pillars for a successful management." Interviewees estimated that collaboration also exhibits the willingness to sharing intelligence and knowledge.

KPIs: The interviewed managers were asked to express their opinion about 11 indicators in this field. They had the perception that the following are important to very important indicators. First, 'Investments in Research \& Development' is a key indicator. WC1 said, "R\&D is important, but it depends on which field, area to invest... If we only focus on the smooth short-term operation, the investment does not need to be high, so this indicator is not important. On the contrary, if we want to broaden and expand existing business and upgrade and improve the attractiveness of tourist attraction and increase visitation, investment in R\&D is a critical indicator." Second, the indicator 'Innovation teamworking (multiskilled and interdisciplinary)' was suggested. "It has a positive impact on the capabilities and skills of staff having different educational backgrounds. It positively influences the forming up of teams from different departments for cooperation in pursuing innovation," LC3 said. Interviewees shared the same opinion about the indicator 'Collaborative and high-achieving environment.' "It is a fairly important indicator; however, it could be put together with the innovation teamworking previously mentioned ... I do not think it is necessary to mention have separate indicator," LC2 said. Another interviewee $(\mathrm{QN})$ pointed out that "High-achieving environment is a difficult concept for me; it is not an easy task to define/0determine the 'high-achieving'. The indicator is useful but vague. I am not in position to assess whether a working environment is high-achieving or not."

The indicator 'Networking' is, in the participants' opinion, very important. "Nowadays, networking is widespread; it is an open channel which can provide useful information about markets, visitors and competitors. We should manage the network systematically and efficiently ... in both medium and long term," GN2 said. The same interviewee argued that "we have to pay attention to business networking, attaining business partnerships and alliances." Almost all interviewees expressed the same perception as GN2.

As for the indicator 'Number of initiatives for process improvement,' WN suggested that "it is not necessary to monitor this indicator in terms of number but management should focus on the improvement's outputs/results." Some of the interviewees considered that merely monitoring 
the volume of initiatives (a quantitative measure) is meaningless; the crucial point is to attain continuous improvement.

The indicator 'Cross-industry comparison (industry benchmarking)' is considered as being fairly important. However, comparison includes many figures and indicators that are confidential, not publishable. HN indicated that "this indicator is positive and to a large extent improving the level of whole industry. Comparison is always good ... but this should be on specific key ratios of performance management." The 'Number of best practices adopted and implemented' is another fairly important indicator, in their perception. It has the feature that it can be easily measured. Nevertheless, the majority of interviewees had the opinion that attractions' industry is developing rapidly and there no really best practices. "Best practices cannot be in one separate area; they should be, in their opinion, more comprehensive including many elements, such as staff allocation and marketing." Regarding the indicator 'Sustainable action plans' (in terms of number of plans supported and/or implemented), all interviewees agreed that this indicator is important. One interviewee expressed the opinion that "We all have to implement practical sustainable action plans in order to achieve desirable outcomes."

Not important indicators, according to interviewed managers' perception, are the following three: (i) 'Number of new services and value propositions,' as nearly two thirds of the interviewees did not think it is necessary to have this indicator. (ii) 'Attract funding (for research and other purposes)' - “Funding? Don't take it seriously. I do not think it is necessary to put this performance indicator," was argued by GN2. (iii) 'Leverage donors and volunteers to drive innovation and change'- "We do not need to consider this indicator; it is a simple as that," ZC said. All interviewees shared the same opinion as they believe that getting donors and volunteers is a kind of mission impossible. Finally, all interviewees expressed the opinion that there no other specific CSFs and KPIs to add/include into the suggested BSC performance template.

\section{Discussion of Main Findings}

The aim of this study was to suggest a framework for performance evaluation in tourist attractions. This aim was addressed by elaborating an evaluation performance template and by investigating its utility and content, i.e., CSFs and KPIs. Based on the above detailed discussion on perceptions/opinions expressed by interviewed managers, we could summarize and discussed the main findings within the context. The BSC approach and tool was regarded as fairly to very useful in evaluating the performance of tourist attractions by the majority of managers. They had the perception that the crafted template is of high value/utility. It encompasses the four domains and perspectives on which strategic management should focus. The key point is to decide on the appropriate CSFs and KPIs to adequately assess the performance.

There was a unanimous agreement that the four perspectives cover all domains of strategic management. Regarding their perception about the important CSFs and corresponding measures in each perspective, the main findings are summarized in the following points. As for the first field (Financial Perspective), two CSFs-'Profitability' and 'Budgetary control'-are regarded as very important. These two factors are adequate to evaluate the performance. 'Accountability and Transparency' and 'Reporting' were seen as not important at all. As for the KPIs 'Revenue/Volume of Sales,' 'Operating Profit,' 'Adhering to budget and meeting targets,' 'Spending/expenditure per visitor,' 'Expand sources of revenue,' and 'Costs management,' these were considered as very important measures. On the contrary, the indicators 'Expenses (as \% of sales)' and 'Auditing and Reporting' were seen as not important to monitor.

In the second field (Customer/Visitor Perspective), two KPAs-'Quality of service and Customer satisfaction' and 'Customer relationship management' (CRM) - were considered as the most important factors. On the contrary, the factor 'Managing Donors and Volunteers' was not seen as an important to monitor and assess. With regard to the KPIs in this field, the indicators 'Visitor experience surveys,' 'Customer satisfaction levels' (implemented along with other measures), 'Complaint rate,' 'Customer retention rate,' and 'Handling comments and complaints on Social Media' were considered as the key 
measures. On the contrary, the following four indicators were seen as not important/useful: 'Quality of services (efficiency): response time' and 'Online reputation management,' 'Support local business and workforce needs' and 'Reward donors and volunteers.'

As for the third field (Internal Processes Perspective), two CSFs-i.e., 'Systems and Processes' and 'Investing in human resources'-were considered as very important. There was unanimous agreement that 'Reliable, clear and precise procedures' and 'Efficiency in terms of time' are very important indicators. 'Participation in grading schemes'/'Accreditation/Certification schemes,' 'Staff development plans,' and 'Level of staff satisfaction and staff retention rate,' were also seen as important indicators. Participants did not consider as important the indicators 'Flexibility in terms of personalization/customization' and 'Productivity.'

In the last field (Innovation \& Learning Perspective) two CSFs-'Developing organization future capabilities and human resources skills and competencies' and 'Collaboration to drive innovation and learning' - were seen as key factors. Indicators seen as fairly important to very important were 'Investments in Research \& Development, 'Innovation teamworking,' 'Collaborative environment,' 'Networking,' 'Number of best practices implemented,' and 'Sustainable action plans.' According to managers' perception, it is not necessary to monitor the following KPIs: 'Number of initiatives for process improvement,' 'Number of new services and value propositions,' 'Attract funding,' and 'Leverage donors and volunteers to drive innovation and change.'

Based on the above discussion, the initially suggested BSC Template has been reviewed and taken a validated form depicted in Table 5 .

Table 5. Final BSC Template for Tourist Attractions (Private- and Public-run).

\begin{tabular}{|c|c|c|}
\hline Perspective & Critical Success Factors & Key Performance Indicators \\
\hline \multirow{2}{*}{ FINANCIAL } & $\begin{array}{l}\text { Profitability and Increase } \\
\text { Shareholder Value }\end{array}$ & $\begin{array}{l}\text { - } \quad \text { Revenue/Volume of sales } \\
\text { - } \quad \text { Operating profit } \\
\text { - } \quad \text { Expand and diversify sources of revenue }\end{array}$ \\
\hline & $\begin{array}{l}\text { Budgetary control (as a means of } \\
\text { controlling and monitoring } \\
\text { performance) }\end{array}$ & $\begin{array}{l}\text { - } \quad \text { Adhering to budget and meeting targets } \\
\text { - } \quad \text { Spending/expenditure per visitor } \\
\text { - } \quad \text { Costs management }\end{array}$ \\
\hline \multirow[t]{2}{*}{ CUSTOMER } & $\begin{array}{l}\text { Quality of service and Customer } \\
\text { satisfaction }\end{array}$ & $\begin{array}{l}\text { - Visitor experience surveys about experience perceptions } \\
\text { - } \quad \text { Customer satisfaction levels } \\
\text { - } \quad \text { Complaint rate and Customer retention rate }\end{array}$ \\
\hline & $\begin{array}{l}\text { Customer relationship } \\
\text { management }\end{array}$ & $\begin{array}{l}\text { - Handling comments on Social Media } \\
\text { - Online reviews }\end{array}$ \\
\hline \multirow{2}{*}{$\begin{array}{l}\text { INTERNAL } \\
\text { PROCESSES }\end{array}$} & Systems and Processes & $\begin{array}{l}\text { - } \quad \text { Reliable, clear and precise procedures } \\
\text { - } \quad \text { Efficiency in terms of time (response time and deadlines) } \\
\text { - } \\
\text { Participation in grading schemes and } \\
\text { Accreditation schemes }\end{array}$ \\
\hline & Investing in human resources & $\begin{array}{l}\text { - Staff development plans (workshops and other } \\
\text { learning forms) } \\
\text { - } \quad \text { Level of staff satisfaction and staff retention rate (in \%) }\end{array}$ \\
\hline \multirow{2}{*}{$\begin{array}{l}\text { INNOVATION/ } \\
\text { LEARNING }\end{array}$} & $\begin{array}{l}\text { Developing organization future } \\
\text { capabilities and human resources } \\
\text { skills and competencies }\end{array}$ & $\begin{array}{l}\text { - Investments in Research \& Development } \\
\text { - Innovation teamworking (multiskilled } \\
\text { and interdisciplinary) }\end{array}$ \\
\hline & $\begin{array}{l}\text { Collaboration (both inter and intra) } \\
\text { to drive innovation and learning }\end{array}$ & $\begin{array}{ll}\text { - } & \text { Collaborative environment } \\
\text { - } & \text { Networking (Alliances, partnerships) } \\
\text { - } & \text { Number of best practices implemented } \\
\text { - } & \text { Sustainable action plans }\end{array}$ \\
\hline
\end{tabular}


It was also found that there are no differences-according to interviewees' perception- in CSFs and KPIs between the two types of tourist attractions, public and private run. Exactly the same factors and indicators should be used in performance evaluation, regardless the type of ownership and management.

The findings of this study confirm those indicated by previous studies. More specifically, the suggestions of Phillips and Louvieris [42], indicating that the core CSFs should be enriched by some additional, for instance the Budgetary control, as a means of controlling and monitoring performance. Results also confirm the suggestions of other studies (see, for instance, $[40,44]$ ) about the flexibility and adaptability to the context of specific industry and settings, with the aim to render the tool more coherent and consistent. The validated template, a framework for assessing performance, seems to be adequate and suitable to the industry of tourist attractions. However, the final form of framework suggested by this study encompasses 22 indicators, a volume double that of what was suggested by Ziegenfuss [48]. The latter study indicated that there should be a maximum of 10 indicators, across the 4 perspectives. The management should focus on more critical activities to avoid the process becoming unwieldy $[45,49]$. Nevertheless, this study suggests 22 indicators, all necessary to properly monitor and evaluate performance in tourist attractions. Additionally, the validated BSC template identifies and includes a maximum of three measures per CSF. For instance, the measures of quality (Internal processes perspective) should be three; the same stands for the measures to capture customer's opinion (Customer perspective). However, Brewer and Speh [44] suggested that one to two measures per aim, should be sufficient.

This study also found that no specific CSFs and KPIs were requested in the context of ST management; no additional factors or indicators were needed to incorporate into the suggested BSC template. Practitioners' opinion is that performance should be monitored and assessed regardless the advent of smart paradigm; technological infrastructure and services are evolving, yet the principles and tools for evaluating performance remain the same.

\section{Conclusions and Management Implications}

The monitoring and evaluation of business performance within the ST management framework is a critical task due to high volume of investments and highly competitive business environment. As such, this managerial function requires strategic planning. The adoption of robust theoretical foundations and adequate approaches, as well as the implementation of suitable frameworks could contribute to the attainment of strategic objectives and related benefits. It is believed that the field of strategic management provides the adequate tools when a long-range planning is considered.

This paper elaborated on and suggested a practicable framework for performance evaluation of business strategy and smart tourism initiatives within the context of tourism attractions. This suggestion was based on the theoretical foundation of SDL. The main aim was to suggest a practical framework for assessing the performance according the BSC approach, an established framework tool of strategic management. It is the argument of this study that the suggested framework constitutes an efficient and effective tool to accomplish the managerial function of monitoring and evaluating business performance.

The crafted framework was empirically tested by means of a qualitative study within the Chinese context. A volume of 30 semi-structured/in-depth interviews with managers from tourist attractions rated grade $4 \mathrm{~A}$ and $5 \mathrm{~A}$ in Zhejiang Province, were conducted to explore and investigate their opinions and perceptions about the value and the elements - CSFs and KPIs - of the suggested template. The ST management framework and the Chinese context were chosen because of the current highly competitive business environment that requires high to very high volume of investments. This requirement renders the ST initiatives business projects that request long-range consideration and strategic planning approach. The literature suggests, and our empirical study confirmed, that the BSC framework is an effective tool for this purpose. The initially crafted framework was reviewed and improved through the testing and validation process, based on the opinion and input from industry practitioners. The study's 
findings advance our understanding and extend knowledge in the field of performance evaluation in tourism settings and context.

It is believed that the present study contributes to the literature and practice as well. From a theoretical perspective, the study's contribution is estimated to be twofold. First, the study adopted a multidisciplinary and integrated approach and analyzed three interrelated streams of literature-business performance evaluation, tourism management and marketing, and smart tourism paradigm - and designed an operational framework that covers all critical domains, CSFs, and the corresponding performance indicators. It is the first study that considers and analyzes this topic in such a manner. Second, it contributes to the field of performance evaluation by adopting a mixed theoretical approach; that is, a framework of strategic management drawing on the theoretical foundation of SDL research stance, which is considered to be mainly a strategic marketing perspective. This approach is a valuable contribution within the context of ST framework where tourist attractions and tourism destinations should have a comprehensive approach tackling and overcoming the traditional barriers between management and marketing. In this regard, the present study argues that SDL stance constitutes a valuable theoretical foundation contributing simultaneously to have a strategic approach to business functions in both fields of management and marketing by designing and implementing the adequate frameworks. The suggested template is a useful tool for this purpose.

Second, the suggested implementable framework for monitoring and evaluating business performance was validated within the Chinese context. By doing so, it contributes to the body of knowledge by extending the implementation of SDL research stance as a theoretical foundation and of the BSC approach in the context of tourist attractions. This framework provides a useful foundation for performance evaluation encompassing the main domains, the key factors and the corresponding indicators suitable to monitor and assess the performance.

The crafted framework was tested by means of qualitative research-i.e., semi-structured interviews-to explore the industry practitioners' perceptions. Findings indicate that the suggested framework constitutes a practical tool and is of high utility to carry out this managerial function. Concerning the CSFs, their number is eight KPAs classified into four perspectives/domains, meaning two CSFs per perspective. The corresponding key indicators (KPIs) are 22, covering the whole range of business functions and activities, current and future, at both strategic and operational levels. All CSFs and KPIs should be considered and implemented in a comprehensive and integrated manner, all being important in assessing performance.

These findings have several implications for industry practitioners (managers and marketers of tourist attractions). Our study suggests a fully implementable and practical framework in terms of operational template that indicates the appropriate consideration of and adequate approach to monitor and evaluate the business performance of tourist attractions. This was regarded by industry practitioners as being of high value and utility. It is quite clear that a comprehensive and integrated approach to performance evaluation, based on a well-crafted tool, contributes to the achievement of strategic aim and operational objectives of tourist attractions within a highly competitive business environment. All CSFs and KPIs are combined in a coherent and consistent manner and provide the potential of effectiveness in the field of monitoring progress and assessing business performance.

The holistic and integrated approach to this managerial function also provides potential and significantly contributes to motivate and mobilize human resources and concentrate financial resources to the specific factors that are considered as important in the sustainable and successful operation of tourist attractions. It also highlights the key activities and processes that skills and capabilities should be focused on to design, craft, and propose the appropriate value propositions to customers, as suggested by SDL theory.

Nevertheless, this study is not without limitations. First, the research methodology has an exploratory nature containing inherent drawbacks. Future empirical studies could implement other qualitative methods (for instance, multiple case studies) to provide further corroboration of the findings. Second, the context of empirical study. The suggested framework for performance evaluation was tested 
and validated within the Chinese context. Study's findings cannot be generalized and automatically extended. Future studies could probably contribute to our knowledge in this field by investigating the same framework in different contexts, different countries from Asia and other continents. Future endeavors should examine the similarities and differences in perceptions of managers of tourist attractions in other countries. These research projects could expand the findings of this study. Third, the practical testing of the suggested template in a time scale, short and medium term. Future empirical studies could explore more deeply the crafted BSC template into practice, how it is implemented and used. The aim should be to identify aspects for improvement and drawbacks to address, as well as to suggest best practices and recommendations to industry practitioners. These studies could also identify the influencing factors and obstacles to the efficient implementation of such tools.

Supplementary Materials: The following are available online at http://www.mdpi.com/2071-1050/12/15/6220/s1, S1: Interview Plan.

Author Contributions: The individual contributions of authors are as follows: Conceptualization, Y.W. and M.S.; methodology, Y.W. and M.S.; software, L.Z.; validation, S.S. and M.S.; formal analysis, Y.W. and S.S.; investigation, S.S. and L.Z.; resources, Y.W. and S.S.; data curation, L.Z.; writing-original draft preparation, S.S. and L.Z.; writing-review and editing, Y.W. and M.S.; visualization, L.Z.; supervision, Y.W. and M.S.; project administration, S.S.; funding acquisition, Y.W. and S.S. All authors have read and agreed to the published version of the manuscript.

Funding: This research was supported by Zhejiang Provincial Natural Science Foundation of China under Grant No. LY20D010001 and Ningbo Municipal Social Science Foundation of China under Grant No. G20-ZX02.

Conflicts of Interest: The authors declare no conflict of interest. The funders had no role in the design of the study; in the collection, analyses, or interpretation of data; in the writing of the manuscript, or in the decision to publish the results.

\section{References}

1. Gretzel, U.; Reino, S.; Kopera, S.; Koo, C. Smart tourism challenges. J. Tour. 2015, 61, 41-47. [CrossRef]

2. Xiang, Z.; Tussyadiah, I.; Buhalis, D. Editorial. smart destinations: Foundations, analytics, and applications. J. Destin. Mark. Manag. 2015, 4, 143-144. [CrossRef]

3. Zhang, L.; Yang, J. Smart tourism. In Encyclopedia of Tourism; Jafari, J., Xiao, H., Eds.; Springer: New York, NY, USA; Wien, Austria, 2016; pp. 862-863.

4. Femenia-Serra, F.; Neuhofer, B. Smart tourism experiences: Conceptualisation, key dimensions and research agenda. J. Regen Res. 2018, 42, 129-150.

5. Gretzel, U.; Sigala, M.; Xiang, Z.; Koo, C. Smart tourism: Foundations and developments. Electron. Mark. 2015, 25, 179-188. [CrossRef]

6. Gretzel, U.; Zhong, L.; Koo, C. Application of smart tourism to cities. Int. J. Tour. Cities 2016, 2, $106-108$. [CrossRef]

7. Gretzel, U. From smart destinations to smart tourism regions. J. Regen Res. 2018, 42, 171-184.

8. Wang, X.; Li, X.R.; Zhen, F.; Zhang, J. How smart is your tourist attraction? Measuring tourist preferences of smart tourism attractions via a FCEM-AHP and IPA approach. Tour. Manag. 2016, 54, 309-320. [CrossRef]

9. Shen, S.; Sotiriadis, M.; Zhang, Y. The influence of smart technologies on customer journey in tourist attractions within the smart tourism management framework. Sustainability 2020, 12, 4157. [CrossRef]

10. Vargo, S.L.; Lusch, R.F. Evolving to a new dominant logic for marketing. J. Mark. 2004, 68, 1-17. [CrossRef]

11. Vargo, S.L.; Lusch, R.F. Service-dominant logic: Continuing the evolution. J. Acad. Mark. Sci. 2008, 36, 1-10. [CrossRef]

12. Prahalad, C.K.; Ramaswamy, V. Co-creation of experiences: The next practice in value creation. J. Interact. Mark. 2004, 18, 5-14. [CrossRef]

13. Merz, M.A.; He, Y.; Vargo, S.L. The evolving brand logic: A service-dominant logic perspective. J. Acad. Mark. Sci. 2009, 37, 328-344. [CrossRef]

14. Li, X. Linking service-dominant logic to destination marketing. In The Routledge Handbook of Tourism Marketing; McCabe, S., Ed.; Routledge: Oxon, UK; New York, NY, USA, 2014; pp. 15-26.

15. McCabe, S. Introduction. In The Routledge Handbook of Tourism Marketing; McCabe, S., Ed.; Routledge: Oxon, UK; New York, NY, USA, 2014; pp. 1-12. 
16. Shaw, G.; Bailey, A.; Williams, A. Progress in tourism management: Aspects of service-dominant logic and its implications for tourism management: Examples from the hotel industry. Tour. Manag. 2011, 32, 207-214. [CrossRef]

17. Cabiddu, F.; Lui, T.W.; Piccoli, G. Managing value co-creation in the tourism industry. Ann. Tour. Res. 2013, 42, 86-107. [CrossRef]

18. Buhalis, D.; Foerste, M. SoCoMo marketing for travel and tourism: Empowering co-creation of value. J. Destin. Mark. Manag. 2015, 4, 151-161. [CrossRef]

19. Boes, K.; Buhalis, D.; Inversini, A. Smart tourism destinations: Ecosystems for tourism destination competitiveness. Int. J. Tour. Cities 2016, 2, 108-124. [CrossRef]

20. Ahn, J.; Back, K.-J.; Barišić, P.; Lee, C.-K. Co-creation and integrated resort experience in Croatia: The application of service-dominant logic. J. Destin. Mark. Manag. 2020, 17, 100443. [CrossRef]

21. Wang, D.; Li, X.; Li, Y. China's smart tourism destination initiative: A taste of the service-dominant logic. J. Destin. Mark. Manag. 2013, 2, 59-61. [CrossRef]

22. Neuhofer, B.; Buhalis, D.; Ladkin, A. Smart technologies for personalized experiences: A case study in the hospitality domain. Electron. Mark. 2015, 25, 243-254. [CrossRef]

23. Buhalis, D.; Amaranggana, A. Smart tourism destinations. In Information and Communication Technologies in Tourism 2014; Xiang, Z., Tussyadiah, I., Eds.; Springer: New York, NY, USA, 2013; pp. 553-564.

24. Mijnheer, C.L.; Gamble, J.R. Value co-creation at heritage visitor attractions: A case study of Gladstone's Land. Tour. Manag. Perspect. 2019, 32, 100567. [CrossRef]

25. Li, H.; Gao, Y.; Zhao, X. Research on digital scenic area with smart transformation. Intell. Build. City Inf. 2011, 7, 112-113.

26. Buhalis, D.; Amaranggana, A. Smart tourism destinations: Enhancing tourism experience through personalisation of services. In Information and Communication Technologies in Tourism 2015; Tussyadiah, I., Inversini, A., Eds.; Springer International Publishing: Cham, Switzerland, 2015; pp. 377-390. [CrossRef]

27. McKinsey. Delivering Value to Customers. Available online: http://www.mckinsey.com/insights/strategy/ delivering_value_to_customers (accessed on 10 February 2020).

28. Edvardsson, B.; Tronvoll, B.; Gruber, T. Expanding understanding of service exchange and value co-creation: A social construction approach. J. Acad. Mark. Sci. 2011, 39, 327-339. [CrossRef]

29. Skalen, P.; Gummerus, J.; Koskull, C.; Magnusson, P. Exploring value propositions and service innovation: A service-dominant logic study. J. Acad. Mark. Sci. 2015, 43, 137-158. [CrossRef]

30. Grönroos, C. Service logic revisited: Who creates value? And who co-creates. Eur. Bus. Rev. 2008, 20, 298-314. [CrossRef]

31. Karpen, I.O.; Bove, L.L.; Lukas, B.A. Linking service-dominant logic and strategic business practice: A conceptual model of a service-dominant orientation. J. Serv. Res. 2012, 15, 21-38. [CrossRef]

32. Grönroos, C. Marketing as promise management: Regaining customer management for marketing. J. Bus. Ind. Mark. 2009, 24, 351-359. [CrossRef]

33. Rather, R.A.; Hollebeek, L.D.; Islam, J.U. Tourism-based customer engagement: The construct, antecedents, and consequences. Serv. Ind. J. 2019, 39, 519-540. [CrossRef]

34. Cirjevskis, A. Designing organizational eco-map to develop a customer value proposition for a "slow tourism" Destination. Adm. Sci. 2019, 9, 57. [CrossRef]

35. Serravalle, F.; Ferraris, A.; Vrontis, D.; Thrassou, A.; Christofi, M. Augmented reality in the tourism industry: A multi-stakeholder analysis of museums. Tour. Manag. Perspect. 2019, 32, 100549. [CrossRef]

36. Pantano, E.; Priporas, C.-V.; Stylos, N. 'You will like it!' using open data to predict tourists' response to a tourist attraction. Tour. Manag. 2017, 60, 430-438. [CrossRef]

37. Fan, D.X.F.; Hsu, C.H.C.; Lin, B. Tourists' experiential value co-creation through online social contacts: Customer-dominant logic perspective. J. Bus. Res. 2020, 108, 163-173. [CrossRef]

38. Gao, L.; Scott, N.; Ding, P. Attributes, theme, and value of a visit to Zhouzhuang, China. J. Destin. Mark. Manag. 2016, 5, 239-248. [CrossRef]

39. Ali, F.; Kim, W.G.; Li, J.; Jeon, H.-M. Make it delightful: Customers' experience, satisfaction and loyalty in Malaysian theme parks. J. Destin. Mark. Manag. 2018, 7, 1-11. [CrossRef]

40. Kaplan, R.S.; Norton, D.P. The balanced scorecard: Measures that drive performance. Harv. Bus. Rev. 1992, 70, 71-79. [PubMed] 
41. Kaplan, R.S.; Norton, D.P. Using the balanced scorecard as a strategic management system. Harv. Bus. Rev. 1996, 74, 75-85.

42. Phillips, P.; Louvieris, P. Performance measurement systems in tourism, hospitality, and leisure small medium-sized enterprises: A Balanced Scorecard perspective. J. Travel Res. 2005, 44, 201-211. [CrossRef]

43. Olve, N.-G.; Roy, J.; Wetter, M. A Practical Guide to Using the Balanced Scorecards; Wiley: Chichester, UK, 1999.

44. Brewer, P.; Speh, T. Using the balanced scorecard to measure supply chain performance. J. Bus. Logist. 2002, 21, 75-93.

45. Kaplan, R.S.; Norton, D.P. Leading change with the balanced scorecard. Financ. Exec. 2001, 17, 64-66.

46. Denton, G.; White, B. Implementing a balanced-scorecard approach to managing hotel operations. Cornell Hotel Restaur. Adm. Q. 2000, 45, 94-107. [CrossRef]

47. Oliveria, J. The balanced scorecard: An integrative approach to performance evaluation. Healthc. Financ. Manag. 2001, 55, 42-46.

48. Ziegenfuss, D. Developing an internal auditing department balanced scorecard. Manag. Audit. J. 2000, 15, 12-19. [CrossRef]

49. Gallo, P.; Mihalcova, B.; Gallo, P.; Cabinova, V.; Tomcikova, L. Application of the balanced score card as a strategic management tool in practice: A case of Slovak tourism sector. GeoJ. Tour. Geosites 2019, 24, 19-28. [CrossRef]

50. Jeong, M.; Shin, H.H. Tourists' experiences with smart tourism technology at smart destinations and their behavior intentions. J. Travel Res. 2019, 0047287519883034. [CrossRef]

51. Buhalis, D. Working Definitions of Smartness and Smart Tourism Destination. 2015. Available online: http://buhalis.blogspot.co.uk/2014/12/working-definitions-of-smartness-and.html/ (accessed on 7 March 2020).

52. Koo, C.; Shin, S.; Gretzel, U.; Hunter, W.C.; Chung, N. Conceptualization of smart tourism destination competitiveness. Asia Pac. J. Inf. Syst. 2016, 26, 367-384. [CrossRef]

53. Finn, M.; Elliot-White, M.; Walton, M. Tourism and Leisure Research Methods; Pearson: Harlow, UK, 2000.

54. Jordan, F.; Gibson, H. Let your data do the talking. In Qualitative Research in Tourism; Phillimore, J., Goodson, L., Eds.; Routledge: Oxon, UK; New York, NY, USA, 2004.

55. Zhejiang Provincial Statistic Bureau. National Bureau of Statistics of China 2013. Available online: http://www.stats.gov.cn/ (accessed on 5 March 2020). (In Chinese)

56. Wikipedia Zhejiang. 2020. Available online: https:/en.wikipedia.org/wiki/Zhejiang (accessed on 12 January 2020).

57. Zhejiang Tourism Bureau. Communiqués and Interviews. 2018. Available online: http://www.stats.gov.cn/ english/PressRelease/201902/t20190228_1651335.html (accessed on 6 March 2020). 